Article

\title{
Adaptation of Human Resources - The Only Viable Solution to a Future Structural Crisis in Romania
}

\author{
Eduard Edelhauser ${ }^{*}$, Roxana Pleșa ${ }^{2}$ \\ Management Department, University of Petrosani, Petrosani, 332006, eduardedelhauser@upet.ro \\ Social Sciences Department, University of Petrosani, Petrosani, 332006, rpmita@yahoo.com \\ * Correspondence: eduardedelhauser@upet.ro; tel: +40-722-562-167
}

\begin{abstract}
The quality of an educational system is reflected not only in the instructive performances of the educational actors, but also in the degree in which it ensures an adequate professional integration. The undergraduate of today, the graduate of tomorrow needs an as accurate as possible information regarding the labour market, which cannot be achieved only by individual means, but also by resorting to carrier counselling services. The motivation of this research is closely connected to the improvement of the level of communication between the two aspects - on the one hand the academic one, by its finite products, and the economic one, on the other hand - and the opportunities that the cooperation between the two aspects might offer: adjusting the demandsupply ratio on the labor market and above all, stopping massive emigration of young graduates of higher education.
\end{abstract}

Keywords: graduate; employer; competencies; employment; labour market; emigration; economic development; educational policies

\section{Introduction}

The concept of sustainable development (or sustainability) is widely used, and nowadays almost everything is under the sign of sustainable development: society is developing through sustainable development; education must become sustainable; research must support sustainable development.

As a matter of principle, sustainable development needs to be applied in all areas of activity in order to meet basic material needs to provide resources to optimize quality of life in health and education. In particular, economic development, like any other type of development, requires measures to increase human resource efficiency in particular.

The concept of sustainable development must be implemented across society, the role of education - in general - and higher education - in particular - being decisive. First, universities need to become sustainable, then reach a sustainable society.

Sustainability is currently treated as more significant in higher education at the global level [1], and as universities begin to consider sustainability as a core value in education, there is a need to contemplate the role of transformative learning in higher education [2]. The basic responsibility of higher education in sustainability includes education for next-generation global citizens focusing on their roles as social leaders and an attitude of respect and dedication to society and care for others [35].

Universities must devote resources intelligently to become sustainable and to provide students with a living experience in a sustainable environment. They must be the catalyst for the necessary changes in society as a whole, and their graduates should be the instruments by which the transformation of the whole society, in the direction of sustainable development, is possible. 
At the level of university education, sustainable development (sustainability) refers to the management of specific processes and activities, always taking into account the fundamental and sustainable objective of increasing the quality of services provided by representative institutions. In the end, these services will be translated into graduates of these well-trained educational institutions, both theoretically and practically, to meet the real needs expressed on the labor market, the needs that are constantly changing (they are in an accelerated process of change) due to technical and technological progress that is manifested in all areas.

Europe's labour market is influenced by the economic changes in the world, first of all by the increase of unemployment of the young, which is in the range of $15.9 \%-21.9 \%$. European policies (the Amsterdam Treaty 1997, the European Strategy for Employment and the Lisbon Strategy 2000, the Memorandum of permanent learning 2001) aim at cutting down unemployment by developing a functional economy, access of all persons to education and efficient carrier counselling systems, development of required competencies of the young graduates for jobs [6].

Labour market dynamics, some of the professions losing ground and others emerging, present economic conditions, all justify the use of carrier counselling and orientation; in their desire to be involved and build up a profession, the young need support and to understand the way labour market works, and need to be able to identify the opportunities provided by it.

Labour market is the "framework where job demand and supply dynamically interact with workforce demand and supply"[7].

Major research done at European level on the young population highlighted the main areas where graduates of higher education are integrated into the labor market: engineering, business and economics, communications sciences and informatics [8,9].

The interest for the insertion of the graduates in the labour market is a constant for the research at national level in Romania. In this sense, we mention the DOCIS- project, "Development of an operational system of qualifications in Romania's academic education". The research brings about a series of significant information and prefigures in a first stage possible future educational policies. Their aim can only be beneficial in a possible balance of the demand and supply in the labour market [10].

All the results of the above mentioned research prove the more and more serious interest for the employability problem area, for the equalization of the ratios between demand and supply on the labour market, for a better monitoring by the universities of the situation of their own graduates, for making curricula more adaptable.

The integration of graduates on the labor market is one of the problems major education. European rules foresee the need for this integration within four months of graduation. This is in the moment is impossible because the knowledge and skills formed in the education system does not correlate close to market needs work and the fact that the labor market has not yet defined its needs education because of the poor competitiveness it has. On the other part the degrees obtained in the educational system do not have value coverage through specific knowledge, so they give false results on knowledge and skills, even if demand and supply are meet.

That is why the steps to be taken to optimize an integration and performance on the labor market target both areas, education and the labor market.

The general objective of the research is, on the one hand, making undergraduates sensitive to the necessity of their being actively involved in various professional contexts, of their concern to look for feedback regarding the activities run, in order to have a clear and integrated image of their own persons as active people on the labour market, and on the other, the possibility of improving the level of communication between the field of education and of the business world, in view of initiating mutual projects in the years to come, having as finality the increase of the level of employability of the University of Petrosani graduates.

This study is structured as follows. Section 1, Introduction, highlights the overall goal of research and the importance of choosing a topic through a brief analysis of previous studies on the need for sustainable development of education. Section 2 presents a fundamental theoretical solid about the importance of higher education for sustainable development, the obligation to reform education policies, the need to balance the supply-demand ratio on the labor market - all these measures to stop 
the massive exodus of the higher education workforce. Section 3 describes the methodology of research, including the research objectives and data collection method. Section 4 also includes two sub-sections: the first, provides the demographic analysis of the phenomenon of emigration in Romania, and the second presents a case study developed in the Jiu Valley conurbation, the area deeply affected by the phenomenon of the labor force emigration, indicating the importance of the correlation between the labor market needs and the outcome of the educational system seen as a saving solution to the financial crisis caused by the emigration phenomenon of young people with higher education. Section 5 presents the findings of the study and conclusions.

The paper has a high degree of novelty, this management analysis aimed to correlate the labor market needs and the output of the education system, is the first of its kind performed in the Jiu Valley. The study will represent the foundation of a process which aims to transform the University of Petrosani in an informal leader of the Jiu Valley conurbation, contributing to the sustainable development of Romanian higher education.

\section{Literature Review}

Education is an essential tool for achieving a sustainable future. In fact, over the last decade, many statements at UN conferences have repeatedly pleaded for education, awareness and awareness raising public awareness on sustainable development.

According to research, education is the one that helps countries achieve their sustainable development goals, impacting productivity growth, health care, and generally raising living standards [11].

Sustainable development is the pursuit of development meeting the needs of the present without compromising the possibilities of future generations to meet their own needs [12].

Education for Sustainable Development, shortly called ESD, is not a particular program, it is more rather, a central point, both for the many forms of education already existing and for those to be created. Sustainable Development Education supports efforts to rethink the program and the education system (methodology and content) of underdeveloped societies [13]. It affects all components of education proper: legislation, politics, finance, curriculum, training, learning, evaluation, etc. Thus, ESD appeals to the process continuous learning and recognizes that the educational needs of people change throughout their lives [14].

In reorienting Education to Sustainable Development, those who develop education programs must strike a balance between the knowledge of the future and of the past, between innovation and tradition.

Education for Sustainable Development pursues and achieves points, such as: increasing the connectivity between human well-being, economics and environmental protection, tending towards a society of eco-affective welfare, enhances the understanding of their own cultural heritage, cultures, justice and development preconditions intercultural and international interaction skills, improves availability and motivation to participate [15], and influence decision-making as citizens and members of the community at work and other communities, offers a variety of vocational skills, creating the necessary acquisitions for the development of each branch of industry in a sustainable direction [16].

Education for Sustainable Development, being a subject of common interest, can only be achieved in a team interdisciplinary, through a joint effort, into a project in which each contributes its own, with the qualities and the defects it has. Relationship with other partners is essential and necessary for creating opportunities learning in society, but also an educational environment that includes basic elements such as: vision, planning, action and reflection, addressing real life issues and issues [16].

In this sense, education for development sustainable at the same time provides a new motivation for the educational act, thus giving the opportunity to those involved participate creatively in identifying solutions and evaluating alternatives for creating a sustainable future.

Taking into account the present way of organizing the education system, referring to us as a strict example the national level, the one in Romania, we find that it currently has certain deficiencies 
at the level equity, quality and relevance to the knowledge economy that, in the long run, can affect both the future of generations present, as well as their successors, shortcomings due to the most likely attempts to reorganize continuous process, but without result. The education system in Romania focuses more on the theoretical level less the practical one, it produces insufficient research and innovation and is not able to promote a Romania competitive and prosperous. In Romania, the field of education is perhaps one of the most reformed areas in the last 22 years [17].

Thus, the process of restructuring the national education system and the new legislative regulations in the sphere education led to the reorganization of the Romanian education network. As a result of the measures within the reform of the national education system, according to a press release of the National Institute of Statistics, in the period 2013-2014, the school population in the national education system was 3,650.9 thousand children, pupils and pupils enrolled students, representing over three quarters of the school-age population (78.2\%) [11].

As many reports indicate, the current performance of the Romanian education system is unsatisfactory, both according to national and international standards. Thus, according to the rankings made in following the PISA tests, Romania is among the countries with an under-education system, which is equivalent to Level 2 on a scale made by McKinsey \& Co with 5 steps - 1 (weak), 5 (excellent) [18].

Of course, the results of an education system depend, to a large extent, on public spending in education, and Romania has a much lower education budget than other EU countries.

A study by McKinsey \& Co [18] has highlighted that improving education has an impact significant on five key economic dimensions: speeding up economic development, strengthening social cohesion, improving health and self-confidence, reducing crime and the costs of justice and strengthening democracy and the concept of citizen. For example, improving PISA scores by only 40 points can lead to a GDP (gross domestic product) growth per capita by $0.9 \%$ in a single generation (30 years), according to the same study.

Also, raising the level of education in Romania is necessary to meet changing requirements on the labor market. Thus, if in $201080 \%$ of EU jobs required a level of qualification average, this figure will rise to $85 \%$ in 2020 , of which $35 \%$ will be jobs with a high qualification [19]. Consequently, improving the education system leads to a reduction in unemployment and risk of poverty, as well as to improve living standards and life expectancy. Moreover, education can reduces the risk of political, commercial and religious manipulation, strengthening democracy and civic involvement [11].

In order to achieve the main goal of ensuring sustainable development through education, above all, an overall forecast has been made on the package of legislative, institutional and regulatory measures general orientation, as well as the realistic financing need [20].

Achieving a sustainable education therefore includes the recognition of the problem, and then, starting from here, to allocate resources, to assume collective responsibility and to build constructive partnerships between the educational environment and the economic environment, from which the young graduates eager to find a job can benefit.

In the medium and long term, as a mandatory condition for transposing the principles of development sustainable development in Romania is a priority objective of strategic importance, radical improvement and diversification the educational offer of the entire education and training system. It is also considered that reforms system and effort and resource investments in this area have a high degree of immobility, capacity absorption being a determining factor, and low rate of return in the short term, tangible results becoming obvious only after a significant number of years.

Currently Romania is still anchored in the models education of industrial education, which no longer correspond present and future realities. Among the main features of this policy are: staff policy that does not provide differentiated career paths didactic is not correlated with the actual needs of schools; an outdated professional training system that ignores the best world practice; an ignorance of the specialists in education materialized through the littleness or lack of demand for studies of analysis, impact and model achievement implementation of reforms; a total lack in the administrative structures of policy makers on education [21] and a lack of total interest in the formation of this type professionals; a non - stimulus wage policy for young people and for performance [22]. 
All these gaps lead to consequences for lack of adaptability of the system to the dynamics of crises, dynamics of innovation and to the dynamics of the workforce [23]. From an economic point of view, all these gaps lead to costs huge by: the lack of efficiency of the education system on the labor market; lack of trust of foreign capital in the labor force of Romania; increasing the confidence of young people in education and economic systems of advanced countries followed by the emigration of an increasing percentage large youth, with dramatic consequences on the workforce in Romania [24].

Thus, full policy change is strictly necessary education through the following measures [22]:

- introduction through collaboration with international institutions a line of high professionalism in education and in policy making on education;

- introducing mandatory feedback mechanisms to ensure the validity and applicability of programs and the prevention of abuse or corruption in the system [25];

- developing quality control education lines to go from the concrete initial data and tracking progress and / or performance;

- $\quad$ conditioning the level of funding by the level of progress and / or performance;

- introduction of the obligation of continuous teacher training correlated with training needs identified through periodic assessments;

- creating parallel funding lines for school units through the participation of private funders [26];

- creating a core curriculum with a level of quality world-wide and modernized as directions [2729]. This desideratum can be achieved through internal development or collaboration with international centers specialized. An international success story is Singapore that has became the world leader on TIMSS by taking over the full curriculum from UK, or China who benefited from the American curriculum formed in the William \& Mary specialist center;

- creating networks of excellence among teachers who want it provide mentoring or tutoring, deepening, acceleration, enrichment within their teaching standard;

- introduction of psycho-pedagogical research techniques such as compulsory training programs [30] ;

- attracting know-how and successful teaching technologies on the international market [31];

- introducing trainers training programs on all the directions of educational policy: "Educate-theEducators" programs [32-35];

- the mandatory introduction of enrichment programs in all forms of education. These programs will ensure permanent modernization and adaptation to the new education system;

- broadening the range of education programs that meet needs the market;

We mention that all these educational policy measures are consistent with EU recommendations and successful experiences international education.

Although inseparable from political implications and implications, understanding the economic effects of migration remains essential in current contexts, such as reforming the labor market or education system [36, 37].

In the face of massive and persistent economic gaps towards the Western Europe, migration is an absolutely inevitable, necessary and potentially beneficial economic mechanism [38]. The beneficial potential has often been highlighted in both the theory and the rhetoric of economic development [39]. However, many of the theoretical effects refer to a moderate migration rate and do not justify a policy of encouraging emigration [40].

The economic effects of migration for those residing in the country are difficult to determine theoretically [41]. They depend, amongst others, on the speed of economic restructuring, the structure of international trade and the exchange ratio, the taxation system and the functioning of the labor and capital markets. And, of course, depend on how many and who is leaving. In the standard paradigm, the country of origin will generally suffer in the short run if migration changes the capitallabor ratio. In the first instance, migration causes a reduction in economic potential and a redistribution of income. The country of origin loses when the economic contribution of migrants was higher than their marginal product, which is always true if the social income from education exceeds private income. 
In the long term, things get much more complicated. Economic theory contains arguments equally plausible both for the assumption of a long-term beneficial effect as well as for the negative effects of migration, of maintaining underdevelopment after capital stock adjustment, by diminishing human capital, lack of investment, and dependence on financial transfers [42].

There are three potential offset mechanisms for the initial negative effects of migration: 1) the economic potential of returning migrants; 2) financial transfers from migrants from abroad; 3) the possible increase in the interest in education in view of the opportunities offered by the work abroad. All three depend on the functioning of the labor market and the education system and can have a significant impact on both [43].

The problem of Romania is complex and started in 2007, which has held a sad record of the working population who emigrated to other countries in search of jobs. If initially this phenomenon (straits) brought Romania a flow of capital through the sending of money to the country by the workers left, along this route phenomenon will cause an economic disaster because after the period adapting the Romanians left will take after them and their families, leaving the force market of work in Romania without workers. This phenomenon correlated with a declining birth rates, puts Romania at risk of being in the future populated by pensioners who will no longer take their pensions from the lack of young people involved in the Romanian labor market.

The ratio of the number of those who work and that of the pensioners has come close to 1 to 1 , and labor productivity a so much so that Romania exports twice as much as it did import.

\section{Methodology}

\subsection{Research Aspects}

Jiu Valley, a former mining region, is facing today with a very difficult situation called depopulation, caused by massive emigration and demographic aging, phenomena leading to major imbalances in the structure of the entire population of Romania. This made us to look for some solutions to solve this problem, solution that must come from our area of competence, higher education for sustainable development. The purpose of this research was to find solutions to sensitize the students about the need to be actively involved in various professional contexts, to be part of the contexts of work, but also to seek feedback on the work conducted, and to gain a clear and integrated future in the labor market. Our research is a pilot study, as a potential employer-employee relationship has been created between the participants in the study, with university graduates benefiting from a professional internship during the last two years of college, at the end of which the employers showed their openness to a contract permanent work. Through this unique experience, both parties have gained: the graduates have gained experience, trust and have formed a clear picture of the labor market since the years of their studies, and employers will be able to recruit qualified staff with higher education and with a profound perception of what the labor market means.

In view of collecting and interpretation of research data, the following aspects have been considered:

- Graduates' perception on their professional direction and development;

- Factors of professional development/indecision;

- Potential motivating/de-motivating factors of their first job;

- Competencies perceived in relation to their own professional course;

- Employers' expectancies and modalities to attract candidates from the university graduates, for their vacant jobs;

- Skills/competencies considered by the employers for recruitment;

- Activities requiring specific competencies for university graduates;

- Limits but also opportunities existing on the present labour market.

\subsection{Study Hypothesis}

We estimate that there are no significant differences between the labor market needs and the outcome of the educational system. 


\subsection{Participants}

The study set sights on over 29 of the most important employers from the Jiu Valley, and 39 of the leading graduates of the University of Petrosani. Data were collected in 2016 year, through a survey oriented as well as for the employees and graduates. The 29 employers are representatives of the most important companies in the area, activating in fields such as: economy, public administration, industry, IT, constructions, tourism, mass media etc, areas of activity that could offset the closure of the mining activity characteristic of the Jiu Valley area. The 39 graduates were chosen on the basis of the competence of the studies, their greatest part being licensed in a single speciality and being motivated to stay in their native country for job search and professional career building. These graduates were beneficiaries of the services of the Centre of Counselling of the University of Petrosani, where they received career and personal marketing services. Moreover, university graduates have been recruited on the academic performance curriculum, in order to benefit from a practice internship during the last two years of faculty, within the representative companies in the Jiu Valley. This measure came as a possible solution to diminish the differences between the needs of the labor market and the claims of those looking for a job available.

\subsection{Research Method and the Instrument Used}

The instrument used for collecting data is a quantitative questionnaire. The research based on the quantitative questionnaire was structured on 21 questions for the employers and other 25 questions for the graduates, of which 8 were common for the two lots of subjects, by which comparable results have been constituted between the requirements and expectations of the two parties involved in the labour market and the work hypothesis has been validated. Statistical data processing was done using SPSS program.

Similarly, the results obtained as a result of processing the questionnaire constituted the basis for the next step, namely the development of a counselling and career plan by which the future graduates of the university might improve their competencies and model their attitudes in agreement with the employers' expectations.

\section{4. $\quad$ Results}

\subsection{Demographic analysis}

The topic of interest in current debates on the issue of migration is the causes of any nature that cause emigrants to leave their native country and nature of economic and demographic effects among countries receiving immigrants. With all neither the causes or the consequences of migration are well understood, nor do they it is obvious how research will develop in the future in this direction. Immigration has become a complex phenomenon, causing controversy in the effort research, especially for the receiving region represented by Europe. In the Europe, the free movement agreement within the European Union paves the way for labor migration across national borders.

Romania subscribes to the phenomenon of global migration, having a historical migration, marked by periods of ascension and decline, mainly based on domestic economic, social and political conditions. Human nature asks for it trying to find better living conditions, naturally more regions developed countries attract people from the poorer parts of the world.

Romania's foreign migration has two sides: a legal, statistical one registered as emigration and immigration, as well as labor migration. The first component is not very important as the size is in the range of 10 to 15 thousand emigrants and several thousand immigrants per year. Relevant is high proportion of migrants with university studies standing at a level close to $25 \%$, the main destination countries being Germany, Italy, Spain, USA and Canada. The significant component of Romanian migration is temporary migration of the labor force.

Starting with 2007, we are witnessing free access to the European market which is favorable both for the creating a European labor market, but also for recording severe slippages in local market.

Figure no. 1 helps for a better understanding of migration and specificity in Romania. We identify five phases of this migration from Romania. 


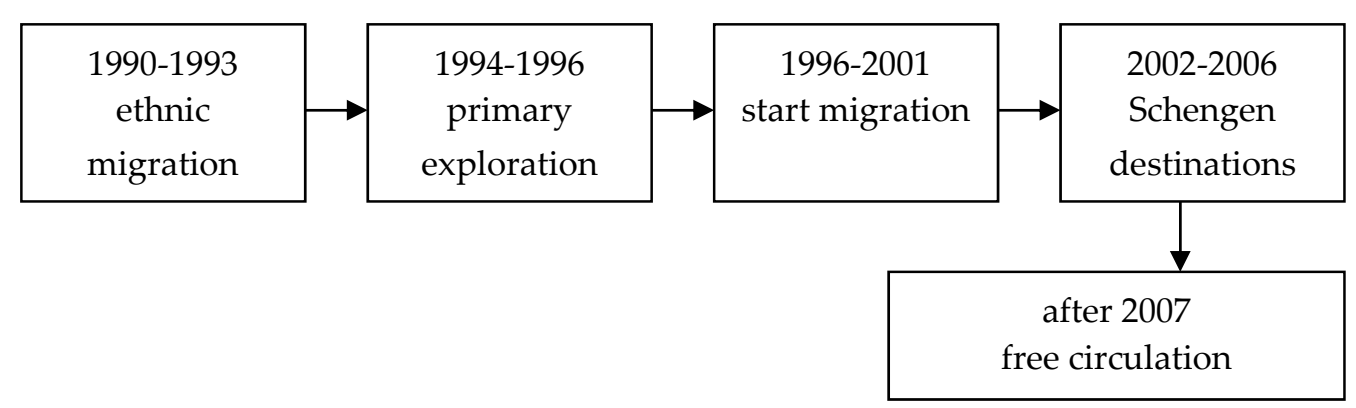

Figure 1. Stages of Romanian emigration after 1989 Source: [44]

Exodus of Romanians in the country reaches alarming odds. The latest United Nations (UN) report shows that our country is the second largest in the world, after Syria, a country hit by a civil war. Specialists say that in a few years, Romania could remain without workforce.

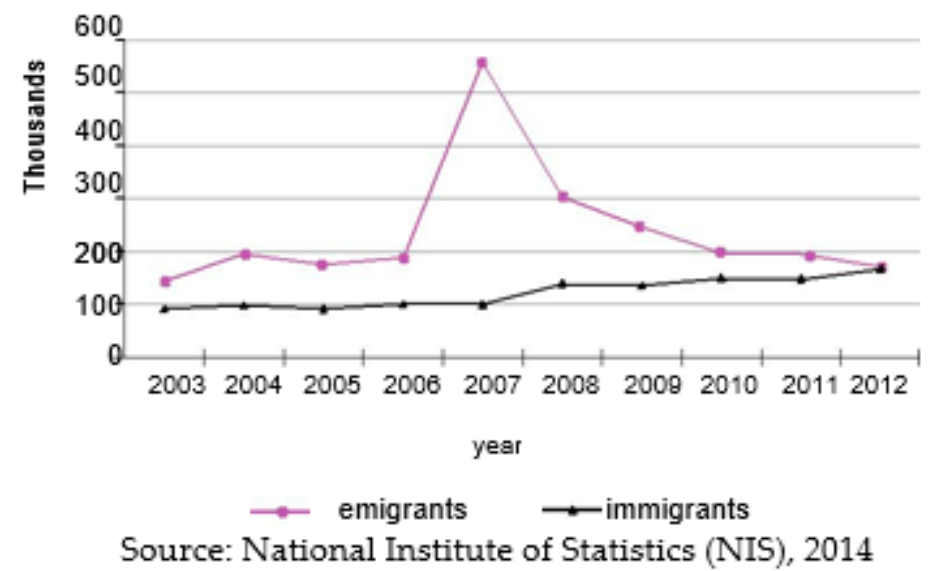

Figure 2. The flow of emigrants and immigrants in 2003-2012 period - Source: National Institute of Statistics (NIS), 2014

A recent analysis, according to Eurostat data for 2015, shows that nine Romanians leave the country each hour, Romania losing the equivalent of an average city every year. Experts say that this year 85,000 Romanians will leave the country and that if the Romanians were to stay, the state budget would earn half a billion euros a year.

Sociologists believe that fostering birth and opening borders for aliens who want to work in Romania could be solutions to cover the loss of workforce. 


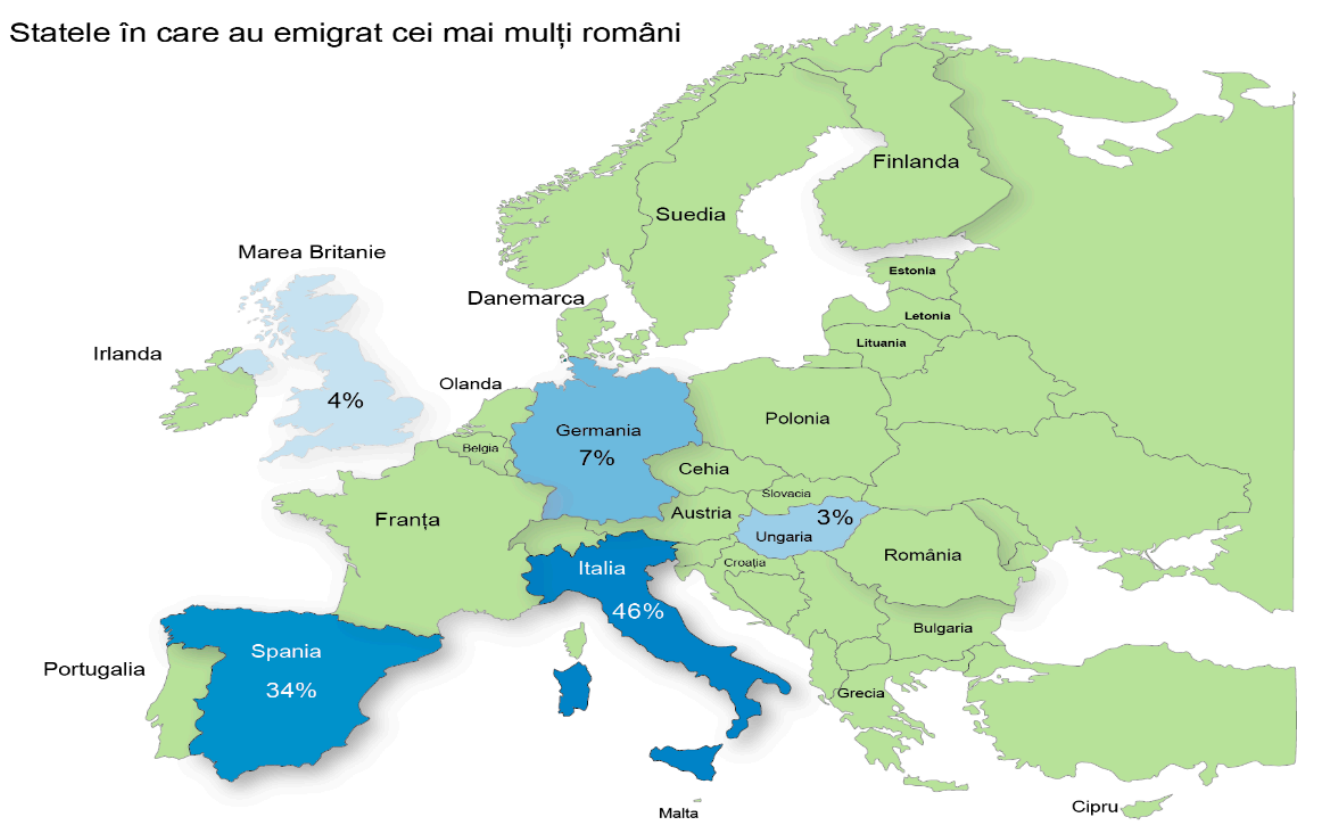

\section{LEGENDĂ}

$+6 \%$ în alte state

Sursă: Institutul Național de Statistică (INS)

Figure 3. States in the European Union where most Romanians emigrated - Source: National Institute of Statistics (NIS)

European statistics show that GDP per capita in Romania is at $50 \%$ of the EU average, while in Spain it reaches $96 \%$ of the European average. It is better to live in Italy, where productivity is $101 \%$ of the EU average, and those in Germany where GDP per capita reaches $123 \%$ of the European average.

On average, a Romanian in Germany wins seven times more than the average annual income of a Romanian resident. At the same time, Romanians left in Italy are five times better, and those who settle in Spain four times as much, according to Eurostat data.

Table 1. The main economic indicators of the countries where most Romanians left

\begin{tabular}{|l|c|c|c|c|}
\hline State & $\begin{array}{c}\text { GDP per } \\
\text { capita } \\
\text { (euros, } \\
2015)\end{array}$ & $\begin{array}{c}\text { Economical } \\
\text { growth } \\
(\% \text { of GDP) }\end{array}$ & $\begin{array}{c}\text { Unemployment } \\
(\%, 2015)\end{array}$ & $\begin{array}{c}\text { Annual net } \\
\text { earnings } \\
(\text { euros, } \\
2015)\end{array}$ \\
\hline Italy & 25.700 & -1.9 & 12.2 & 19.359 \\
\hline Spain & 22.300 & -1.3 & 26.4 & 16.818 \\
\hline Germany & 32.600 & 0.4 & 5.3 & 26.485 \\
\hline Romania & 6.500 & 2.2 & 7.3 & 3.606 \\
\hline
\end{tabular}

Source: EUROSTAT

Changes that took place after 1989- year that meant the fall of the communist regime and the adoption of a Western model- in demographic trends and in the structure of the Romanian population as a consequence of the economic and social transition are reflected in the demographic situation of the country.

Romania's population has fallen for the last 29 years and there are still no signs for visible recovery. Decrease in population may be the result separately or cumulated three factors:

- $\quad$ negative net external migration higher than natural growth;

- increasing the mortality rate that exceeds the birth rate;

- rebound in birth rate below the mortality rate. 
Increasing the size of international migration predominantly among the working age population will in the medium and long term determine major problems at the labor market level in the pension system and in general in the financing of social services.

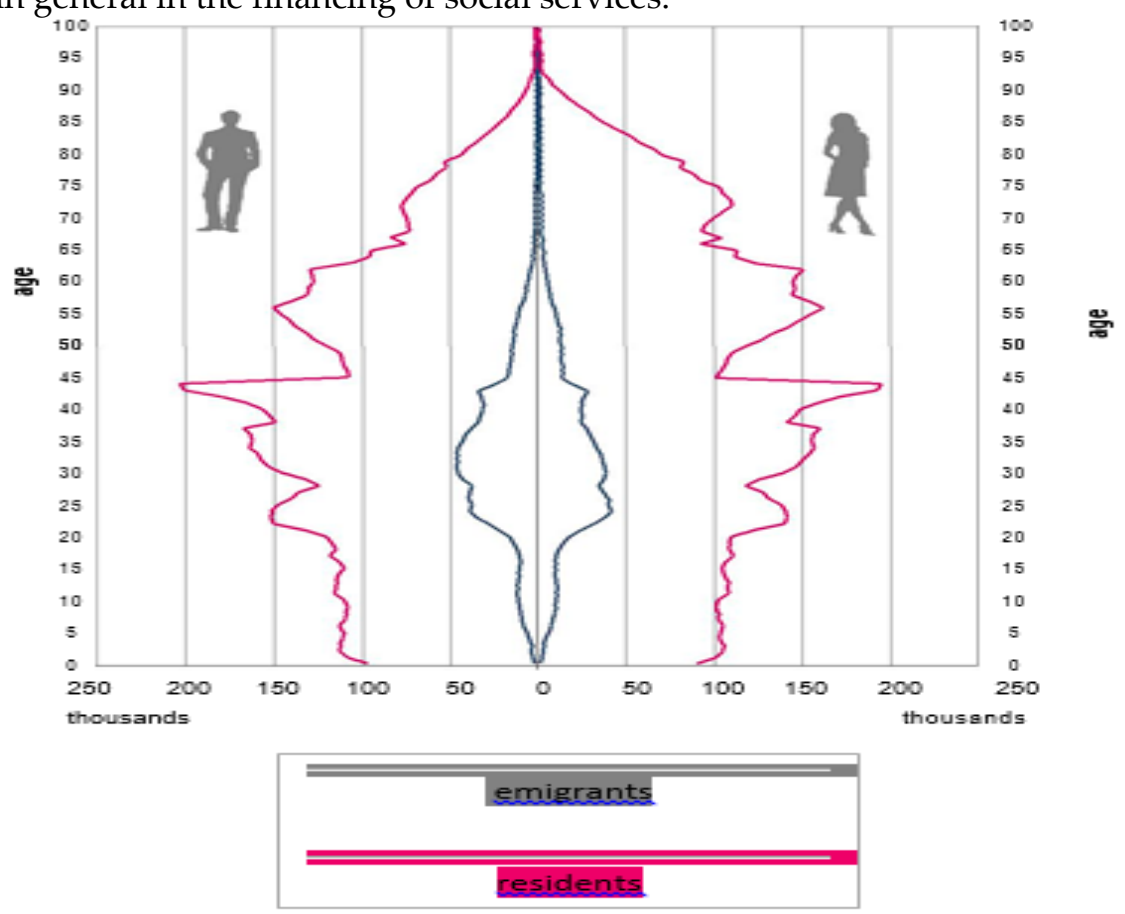

Figure 4. The resident population of Romania and the number of emigrants on 1 January 2012 by age and gender - Source: National Institute of Statistics (NIS), 2014 
4.2. The comparative analysis between the Labor Market needs and the output of the Educational System. Case Study: Jiu Valley conurbation, Romania

\subsubsection{Recruitment Process and Sources of Information}

The essence of professional selection activity is efficiently done when two categories of information are compared, namely: number and requirements of vacant jobs and qualities of those looking for a job. In the process of professional selection the expertise of work capacity intervenes, this representing the identification of the existing agreement between the individual and the profession, more accurately, between the physical and psycho-social availability of the individual and the professional requirements [45].

The candidates' recruitment process is based on the use of a variety and modality of attracting graduates from higher education towards available jobs. From the answers given by the employers of the top firms in Jiu Valley, more than $40 \%$ are based either on recommendations (48.3\%), or on direct approach of the candidates $(44.8 \%)$, and more than one quarter are based on information found on job sites. Unfortunately only $10 \%$ attract the candidates by promotion actions in university centres.

In view of obtaining as detailed information as possible regarding competencies and knowledge expected by employers to be found with University of Petrosani graduates, we have been looking both for key competencies, proposed in a Recommendation of the European Parliament, and for competencies/knowledge that are specific to domains of companies involved in research.

A part of the competencies centralized as a result of the analysis of the participants' responses, are also to be found in the table with key competencies, developed at UE level. We wish to underline that these classifications do not exclude each other; they help us create a detailed picture of the companies' expectations regarding skills of graduates. We feel that these competencies should increase the employability level for the all graduates of the University of Petrosani, current and future generations.

In general, these are the main competencies the employers wish to find with the future candidates:

- communication -within the company and with its clients as well;

- creativity -absolutely necessary in solving problems;

- critical thinking - useful in processing situations - analysis and synthesis - for information of speciality and more;

- $\quad$ initiative - closely connected to project initiation;

- $\quad$ time management - to meet deadlines, but also to solve work tasks;

- permanent learning - development, but also availability to transmit, take over, assimilate information received from colleagues, superiors or in training sessions;

- team work and cooperation.

Fig. 5 shows that most of the employers participating in the study consider that the education of candidates is very important $(95.8 \%)$, but also their skills (77.7\%). Recommendations in favour of the candidate are appreciated by more than $60 \%$, and the reputation of the higher education institution is appreciated by approx. $40 \%$ of the respondents. 

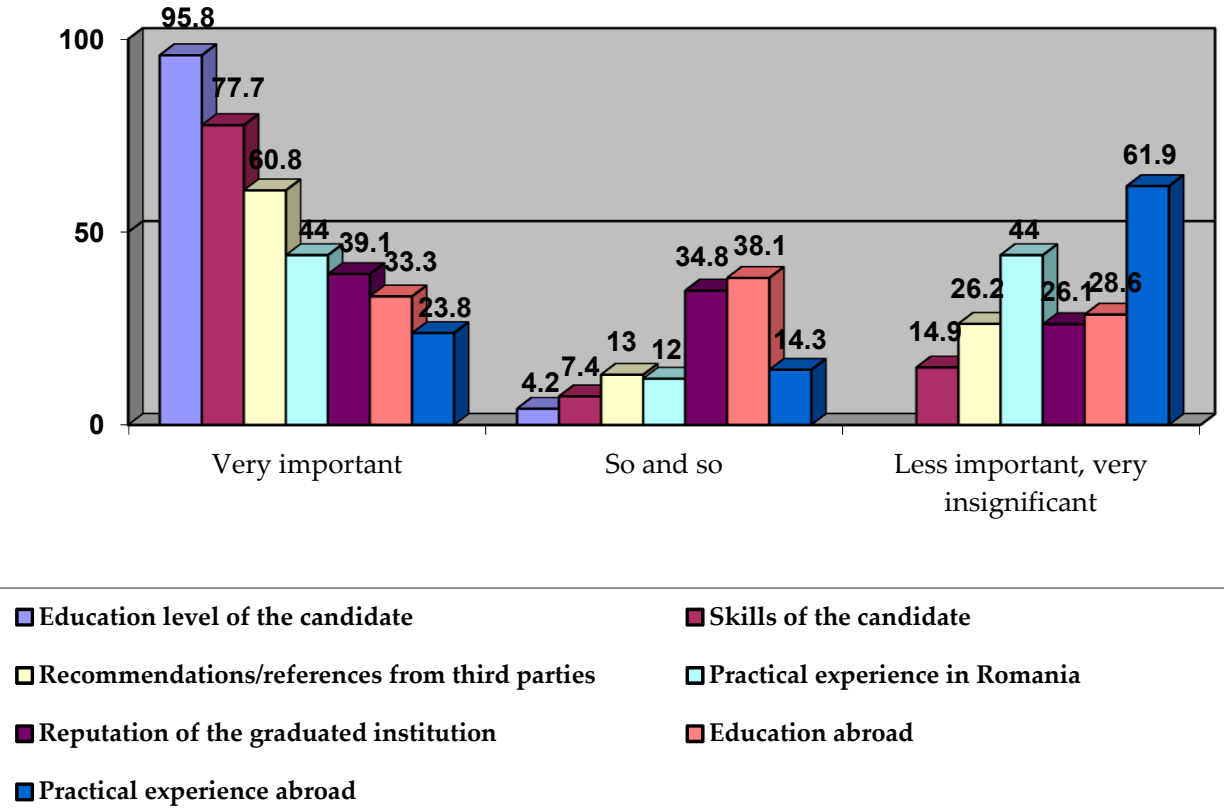

Figure 5. Importance of the following aspects in the recruitment process (\%)

It is already known that when a university is graduated, the objectives in life are formulated generally, and the perception on the professional future is vague. Being in a continuous process of knowing their own selves, graduates will need instruments, strategies and methods that might help them discover themselves from a professional point of view, understand individual resources, but also their limits, so that they might build up medium and long term objectives, starting from these personal evaluations, being able to discover their abilities, but also their weak points in relation to a carrier they intend to develop.

Considering the psychological and social characteristics specific to the graduates' age range, the information reaching them, the confidence shown in the information sources, as well as the critical thinking, the way in which information is processed, are all essential factors in carrier decisions assumed by them.

We would like to point out the graduates' sources of information, their direct experience with those, and the perception/confidence shown to various information sources - all these positively contributing to diminishing the lack of information regarding the carrier choice made, declared by more than two thirds of the respondents.

The graduates had the opportunity to choose among various sources of information, all those being able to represent a point helping them to choose their jobs. Of the items allotted to information sources, declared by the graduates as having been resorted to for information, three view direct contact of the graduate with factors of influence in professional decision. Thus, job markets are preferred by approximately $85 \%$ of the subjects, direct approach of the employers (38\%), but also Public Placement Agencies (28\%). Internet/mass media is used by more than three quarters of the graduates.

An important aspect for the approach of materials and methods of popularization of carrier orientation services is the impact perceived by the student for the information sources and the confidence allotted to various sources, when facing carrier decision. The carrier orientation materials for undergraduates should show the openness of the carrier centres to cooperation with institutions in private or state institutions. Job or internship opportunities should be presented, direct contact with employers should be mentioned, since such services are considered to be important, therefore they are looked for when appealing to carrier counselling services. Similarly, the undergraduates need to be informed on the fact that carrier centres can offer more than mediation between the undergraduate and possible employers. 


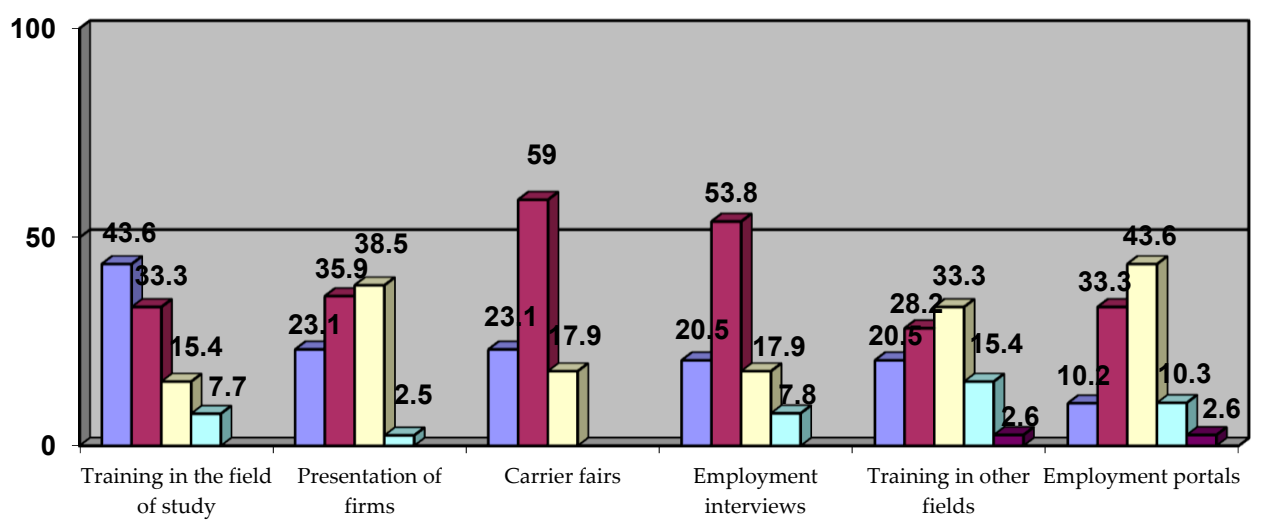

\section{$\square$ Very much important $\square$ Very important $\square$ Adequately important $\square$ Not so important $\square$ Less important}

Figure 6. Importance given to the following sources of information in career (\%)

Lack of self knowledge, of exploration of employment opportunities, preponderant centering on identification of a possible employer, without putting into balance one's own interests or values, make the entire decision process unsatisfactory. To this one might add the fact that most of the graduates put the responsibility for developing professional competencies on the University instead of their own person. The fact that the support in the professional course is done by academic means is a plus for the undergraduates, since it meets the needs and expectations manifested. Meanwhile, however we should take into account the fact that there is a risk of transforming the undergraduates into simple receptors. It is necessary to maintain the responsibility and confidence attributed to the academic environment, and meanwhile to encourage the development and assuming of one' own responsibility by offering practical exercises that might be achieved outside the academic environment, by orientation toward labour market, by support offered in developing a personal brand and training in social networks that might assist them in their professional course.

These conclusions allow us draw up carrier orientation and counselling programmes that would make first of all undergraduates sensitive to the importance of being actively involved in all the stages of professional course, assuming critical view on the information obtained and developing practical competencies regarding the selected activity area.

\subsubsection{Professional development}

\subsubsection{Professional skills and competencies}

Out of a list of 18 abilities/competencies subject to analysis of both university graduates and employers in various domains, with whose help we intended to the see the level of self knowledge of the young at graduation, on the one hand, and on the other, the suggestions of the representatives of Jiu Valley labour market addressed to higher education institutes in Romania regarding training these competencies among their educational products.

Out of the responses of the respondents, in a hierarchy of the first eight points in the order of importance, we notice the same skills, with negligible differences. However, the percentage is averagely slightly higher in the evaluations made by employers regarding all the 18 skills/competencies. This is explicable also due to the fact that, as they describe themselves, most of the graduates are in a process of knowing themselves, being at the level at which they should practice various competencies in a safe context, learning about them, discovering their skills, but also their weak points related to the carrier they wish to build up. 


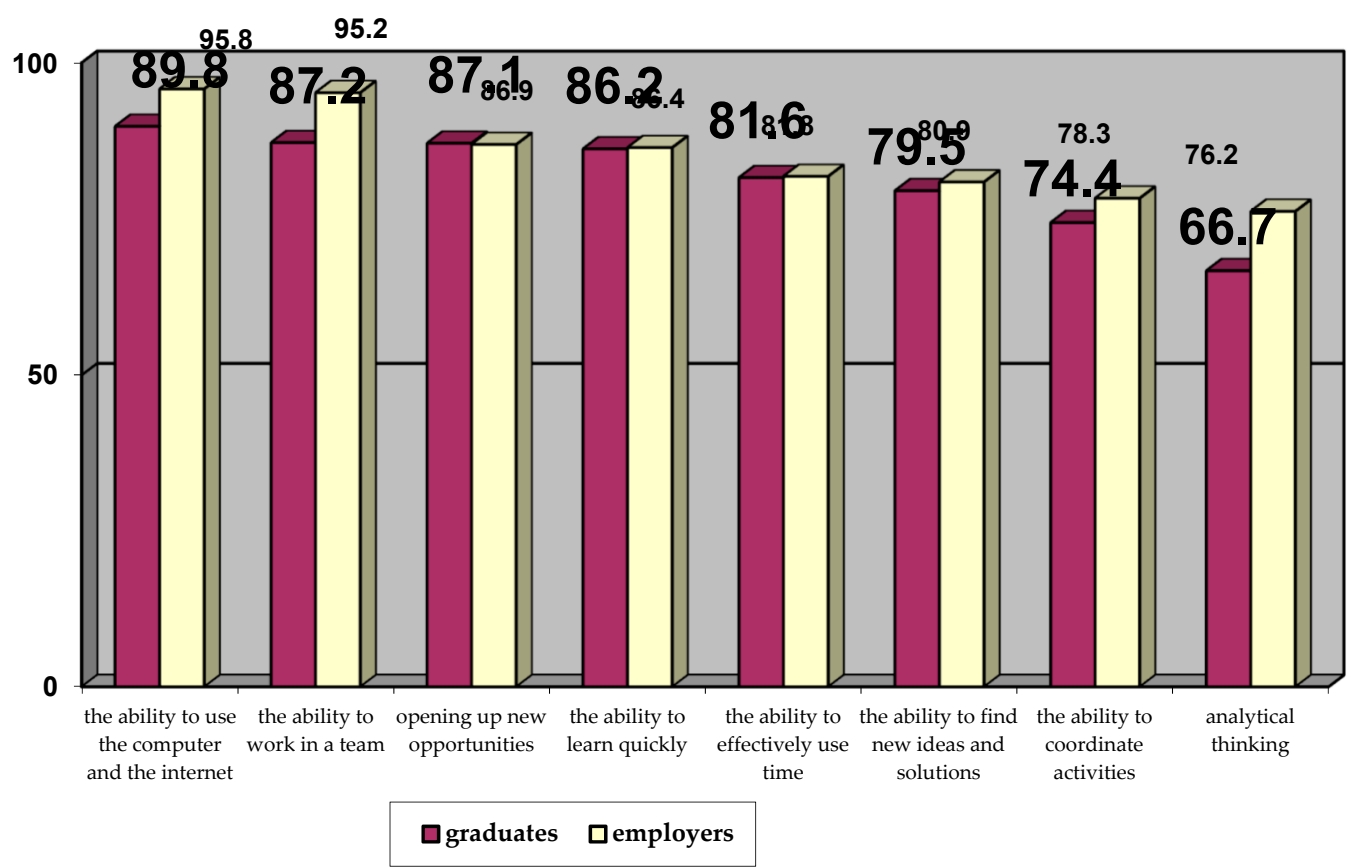

Figure 7. Importance of competencies in the opinion of the graduates and employers (\%)

It is important to point out the percentage differences regarding evaluation of analytical thinking skill, (66.7\% among the graduates and $76.2 \%$ among the employers), a potential explanation owing to a different level of maturity and life experience.

Tables 2 and 3 highlight the mean of the answers of the graduates and the employers, and the data presented in them support the study hypothesis, with no significant differences of opinion between the two groups of respondents.

Table 2. Mean of the answers of the two groups of subjects regarding the importance of the activities necessary for the accumulation of professional experience

\begin{tabular}{|c|c|c|c|c|c|c|}
\hline $\begin{array}{l}\text { Status } \\
\text { respondent }\end{array}$ & $\begin{array}{l}\text { The } \\
\text { importance of } \\
\text { activities } \\
\text { involving the } \\
\text { manipulation } \\
\text { of objects, } \\
\text { machines and } \\
\text { tools in the } \\
\text { accumulation } \\
\text { of professional } \\
\text { experience }\end{array}$ & $\begin{array}{l}\text { The } \\
\text { importance of } \\
\text { research and } \\
\text { investigation } \\
\text { of phenomena } \\
\text { in different } \\
\text { fields and in } \\
\text { different } \\
\text { forms in the } \\
\text { accumulation } \\
\text { of professional } \\
\text { experience }\end{array}$ & $\begin{array}{l}\text { The } \\
\text { importance of } \\
\text { less } \\
\text { structured, } \\
\text { artistic } \\
\text { activities that } \\
\text { involve } \\
\text { creativity and } \\
\text { self- } \\
\text { expression in } \\
\text { the } \\
\text { accumulation } \\
\text { of professional } \\
\text { experience }\end{array}$ & $\begin{array}{l}\text { The } \\
\text { importance of } \\
\text { activities } \\
\text { involving } \\
\text { interpersonal } \\
\text { relationships, } \\
\text { helping } \\
\text { others, } \\
\text { educational } \\
\text { activities in } \\
\text { the } \\
\text { accumulation } \\
\text { of professional } \\
\text { experience }\end{array}$ & $\begin{array}{l}\text { The importance } \\
\text { of } \\
\text { entrepreneurial } \\
\text { activities, } \\
\text { involving } \\
\text { initiative and } \\
\text { coordination of } \\
\text { one's own } \\
\text { activity or a } \\
\text { group in the } \\
\text { accumulation } \\
\text { of professional } \\
\text { experience }\end{array}$ & $\begin{array}{l}\text { The } \\
\text { importance of } \\
\text { repetitive } \\
\text { activities that } \\
\text { involve the } \\
\text { systematic and } \\
\text { orderly } \\
\text { manipulation } \\
\text { of data or } \\
\text { objects in a } \\
\text { well- } \\
\text { organized } \\
\text { setting and } \\
\text { defined in the } \\
\text { accumulation } \\
\text { of professional } \\
\text { experience }\end{array}$ \\
\hline Graduates & 3.46 & 3.74 & 3.26 & 4.08 & 4.36 & 3.64 \\
\hline Employers & 3.58 & 3.72 & 3.28 & 3.88 & 4.27 & 3.59 \\
\hline
\end{tabular}

Table 3. Mean of the answers of the two groups of subjects regarding the agreement on various statements related to professional competencies 


\begin{tabular}{|c|c|c|c|c|c|c|c|}
\hline $\begin{array}{l}\text { Status } \\
\text { respondent }\end{array}$ & $\begin{array}{l}\text { Agreement } \\
\text { with the } \\
\text { statement: } \\
\text { employers are } \\
\text { more } \\
\text { interested in } \\
\text { the skills of } \\
\text { the graduates } \\
\text { and the } \\
\text { previous } \\
\text { work } \\
\text { experience, } \\
\text { and less the } \\
\text { graduate } \\
\text { specialization } \\
\text { or the prestige } \\
\text { of } \\
\text { university the }\end{array}$ & $\begin{array}{l}\text { Agreement } \\
\text { with the } \\
\text { statement: for } \\
\text { both } \\
\text { graduates } \\
\text { and } \\
\text { recruiters, the } \\
\text { competences } \\
\text { acquired in } \\
\text { the } \\
\text { curriculum } \\
\text { occupy a } \\
\text { secondary } \\
\text { place in } \\
\text { relation to } \\
\text { transversal } \\
\text { competencies }\end{array}$ & $\begin{array}{l}\text { Agreement } \\
\text { with the } \\
\text { statement: In } \\
\text { finding the } \\
\text { first job, the } \\
\text { competencies } \\
\text { of teaming in } \\
\text { a team are } \\
\text { more } \\
\text { important } \\
\text { than those } \\
\text { acquired in } \\
\text { the study } \\
\text { programs }\end{array}$ & $\begin{array}{l}\text { Agreement } \\
\text { with the } \\
\text { statement: } \\
\text { the } \\
\text { knowledge } \\
\text { and skills } \\
\text { that } \\
\text { employees } \\
\text { need at the } \\
\text { workplace } \\
\text { are } \\
\text { acquired at } \\
\text { the } \\
\text { workplace, } \\
\text { and less } \\
\text { during } \\
\text { academic } \\
\text { studies }\end{array}$ & $\begin{array}{l}\text { The } \\
\text { agreement } \\
\text { with the } \\
\text { statement: } \\
\text { how to } \\
\text { present the } \\
\text { interview } \\
\text { and } \\
\text { personality } \\
\text { are the } \\
\text { factors that } \\
\text { have the } \\
\text { greatest } \\
\text { importance } \\
\text { in getting } \\
\text { the first job }\end{array}$ & $\begin{array}{l}\text { Agreement } \\
\text { with the } \\
\text { statement: } \\
\text { employers } \\
\text { place the } \\
\text { knowledge } \\
\text { of a foreign } \\
\text { language } \\
\text { and the } \\
\text { computer } \\
\text { skills are of } \\
\text { equal } \\
\text { importance } \\
\text { to the way } \\
\text { the } \\
\text { interview is } \\
\text { presented } \\
\text { and to the } \\
\text { type of } \\
\text { personality }\end{array}$ & $\begin{array}{l}\text { Agreement } \\
\text { with the } \\
\text { statement: in } \\
\text { the opinion } \\
\text { of the } \\
\text { recruiters, } \\
\text { the results of } \\
\text { the } \\
\text { bachelor's } \\
\text { examination } \\
\text { and } \\
\text { reputation of } \\
\text { the } \\
\text { university } \\
\text { are not at all } \\
\text { important in } \\
\text { the } \\
\text { employment } \\
\text { decision }\end{array}$ \\
\hline Graduates & 4.41 & 3.59 & 3.79 & 4.03 & 4.23 & 4.10 & 3.41 \\
\hline Employers & 3.70 & 3.17 & 3.50 & 3.88 & 3.79 & 3.68 & 3.30 \\
\hline
\end{tabular}

Figure 8 points out another comparative analysis between the two lots of subjects, which highlights the only notable differences of opinion across research, and by calculating the Spearman correlation coefficient, statistically significant negative correlations are revealed (table 4, 5, 6).

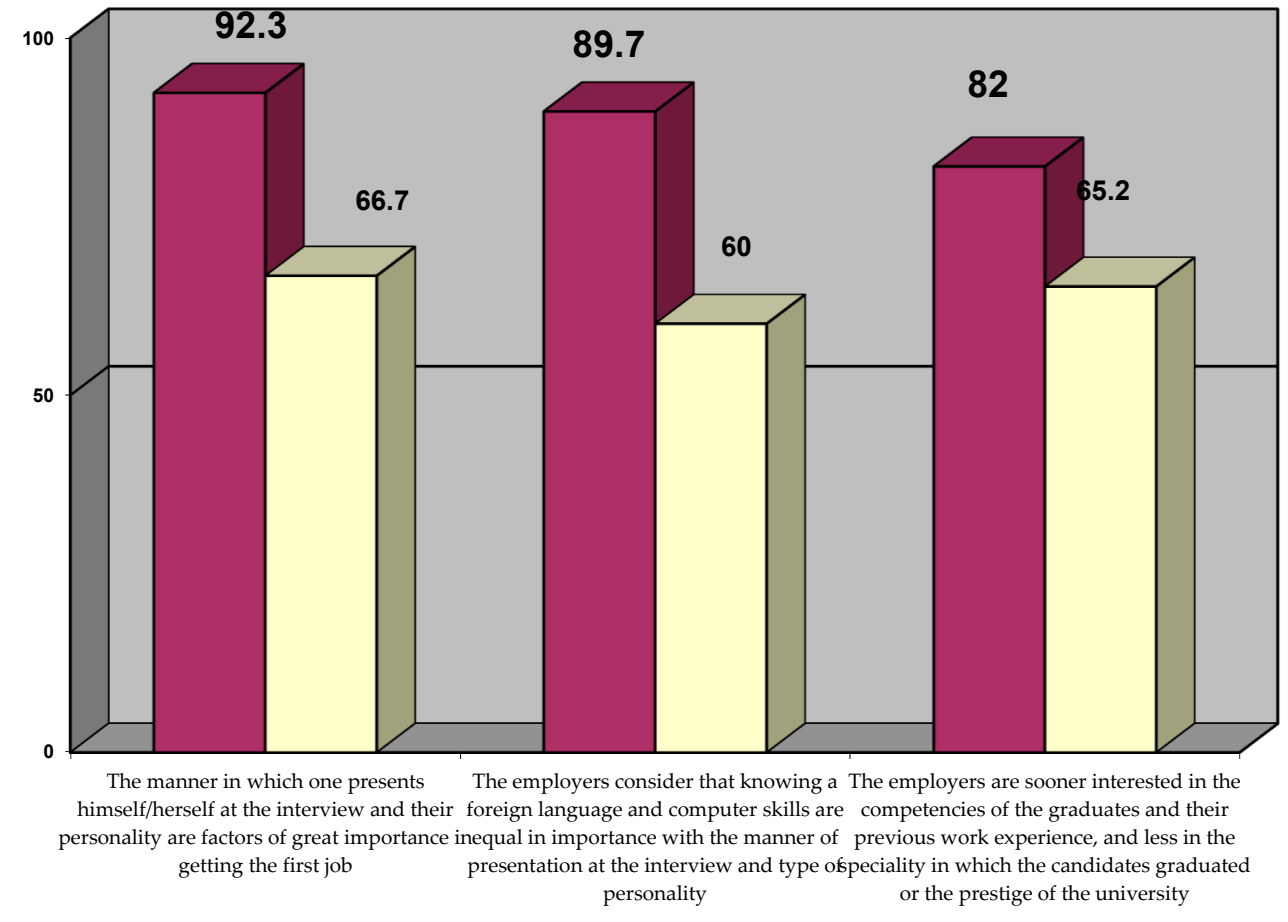

口graduades 口employers

Figure 8. Importance of the following aspects in the opinion of the graduates and employers (\%) 
Table 4. Correlation between agreement with the statement: employers are more interested in the skills of the graduates and the previous work experience, and less the graduate specialization or the prestige of the university and status of respondent

\begin{tabular}{|c|c|c|c|}
\hline \multicolumn{2}{|c|}{} & $\begin{array}{c}\text { Status of } \\
\text { respondent }\end{array}$ \\
\hline $\begin{array}{c}\text { Spearman's } \begin{array}{c}\text { Agreement with the statement: Employers are more } \\
\text { rho }\end{array} \\
\text { interested in the skills of the graduates and the previous } \\
\text { work experience, and less the graduate specialization or } \\
\text { the prestige of the university }\end{array}$ & $\begin{array}{c}\text { Correlation } \\
\text { Coefficient }\end{array}$ &,$- 395^{* *}$ \\
\cline { 3 - 4 } & \begin{tabular}{c} 
Sig. (2-tailed) \\
\cline { 3 - 4 }
\end{tabular} & $\mathrm{N}$ & 62 \\
\hline
\end{tabular}

**. Correlation is significant at the 0.01 level (2-tailed).

Table 5. Correlation between agreement with the statement: interviewing mode and personality are the factors that have the greatest importance in getting the first job and status of respondent

\begin{tabular}{|c|c|c|c|}
\hline \multicolumn{2}{|c|}{} & $\begin{array}{c}\text { Status of } \\
\text { respondent }\end{array}$ \\
\hline \begin{tabular}{c} 
Spearman's $\begin{array}{c}\text { Agreement with the statement: interviewing mode and } \\
\text { rho } \\
\text { personality are the factors that have the greatest } \\
\text { importance in getting the first job }\end{array}$ \\
\cline { 3 - 4 }
\end{tabular} & $\begin{array}{c}\text { Correlation } \\
\text { Coefficient }\end{array}$ &,$- 335^{* *}$ \\
\cline { 3 - 4 } & \begin{tabular}{c} 
Sig. (2-tailed) \\
\cline { 3 - 4 }
\end{tabular} & $\mathrm{N}$ & 603 \\
\hline
\end{tabular}

**. Correlation is significant at the 0.01 level (2-tailed).

Table 6. Correlation between agreement with the statement: employers place the knowledge of a foreign language and computer skills are of equal importance to how to present the interview and the type of personality and status of respondent

\begin{tabular}{|c|c|c|c|}
\hline & & & $\begin{array}{c}\text { Status of } \\
\text { respondent }\end{array}$ \\
\hline \multirow[t]{3}{*}{$\begin{array}{c}\text { Spearman's } \\
\text { rho }\end{array}$} & \multirow{3}{*}{$\begin{array}{c}\text { Agreement with the statement: employers place the } \\
\text { knowledge of a foreign language and computer skills are } \\
\text { of equal importance to how to present the interview and } \\
\text { the type of personality }\end{array}$} & $\begin{array}{l}\text { Correlation } \\
\text { Coefficient }\end{array}$ &,$- 278^{*}$ \\
\hline & & Sig. (2-tailed) & 026 \\
\hline & & $\mathrm{N}$ & 64 \\
\hline
\end{tabular}

*. Correlation is significant at the 0.05 level (2-tailed).

\subsubsection{Professional experience}

The comparison between the two lots of subjects of the study points out a perfect match of the hierarchy of activities intended to accumulation by the graduates of professional experience, the idea that supports the hypothesis of our study. Thus, in a percentage of over $85 \%$, both graduates and employers rate first in the process of acquiring professional experience, entrepreneurial activities, which involve initiative and coordination of one's own activity or of a group's, followed by activities involving interpersonal relationships, helping the others, educational activities, appreciated by more than three quarters of the respondents. 


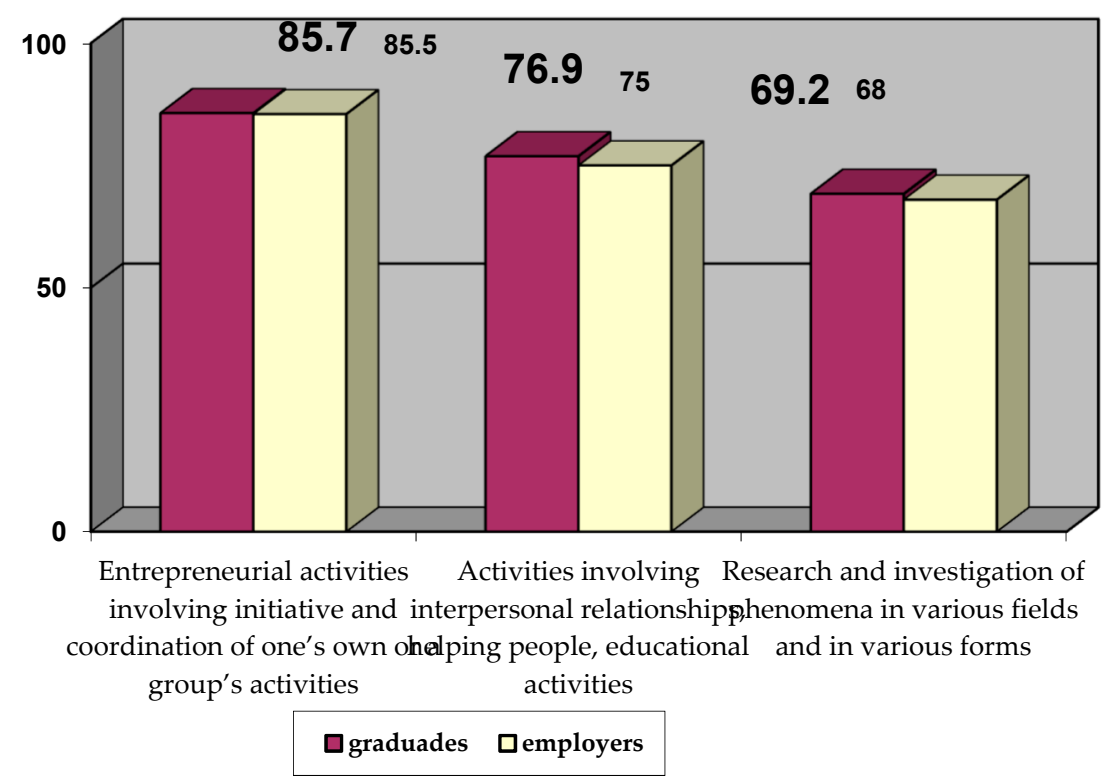

Figure 9. Importance of the following activities for accumulation of professional experience by graduates $(\%)$

\subsubsection{Carrier interests and decisions}

Even if there was no long term contact with labour market, the graduates' interests are important, especially in the perspective of their being taken to the reality offered by labour market and competencies proven in professional domains by them. Work context is very important for the young, they preferring certain characteristics of a potential workplace.

As a result of the motivation evaluation, we found that the principal motivating factors in the evaluation of a job by the responding graduates, are:

- Possibility of acquiring new knowledge in the field of their interest;

- Possibility to advance in their carrier;

- Good communication between departments and colleagues;

The main de-motivating factors, in case the undergraduates would be confronted with those, are:

- Lack of interactivity within a department;

- An environment with reduced possibilities of professional development;

- Possible deficient team organization.

We offered the graduates a list of possible expectancies for the desired job. Out of those, recognition of professional merits is preferred by $43 \%$, motivating conditions for improvement and promotion a little more than $40 \%$, and material advantages are preferred by one third. 


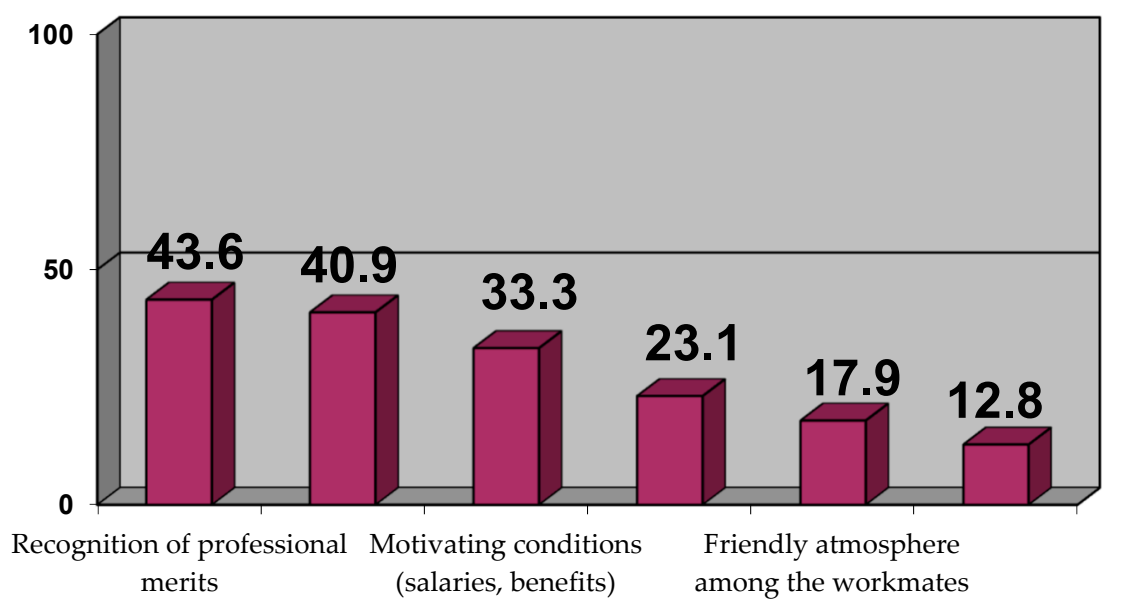

Figure 10. Graduates' expectations for the selected job (\%)

In looking for jobs, both young graduates and employers have a series of expectations, one of them realist, pertinent, others less so. Depending on the requirements and expectations of the employers, the stability of the labour market is determined, while part of the employees stay or are even promoted, others leave the company.

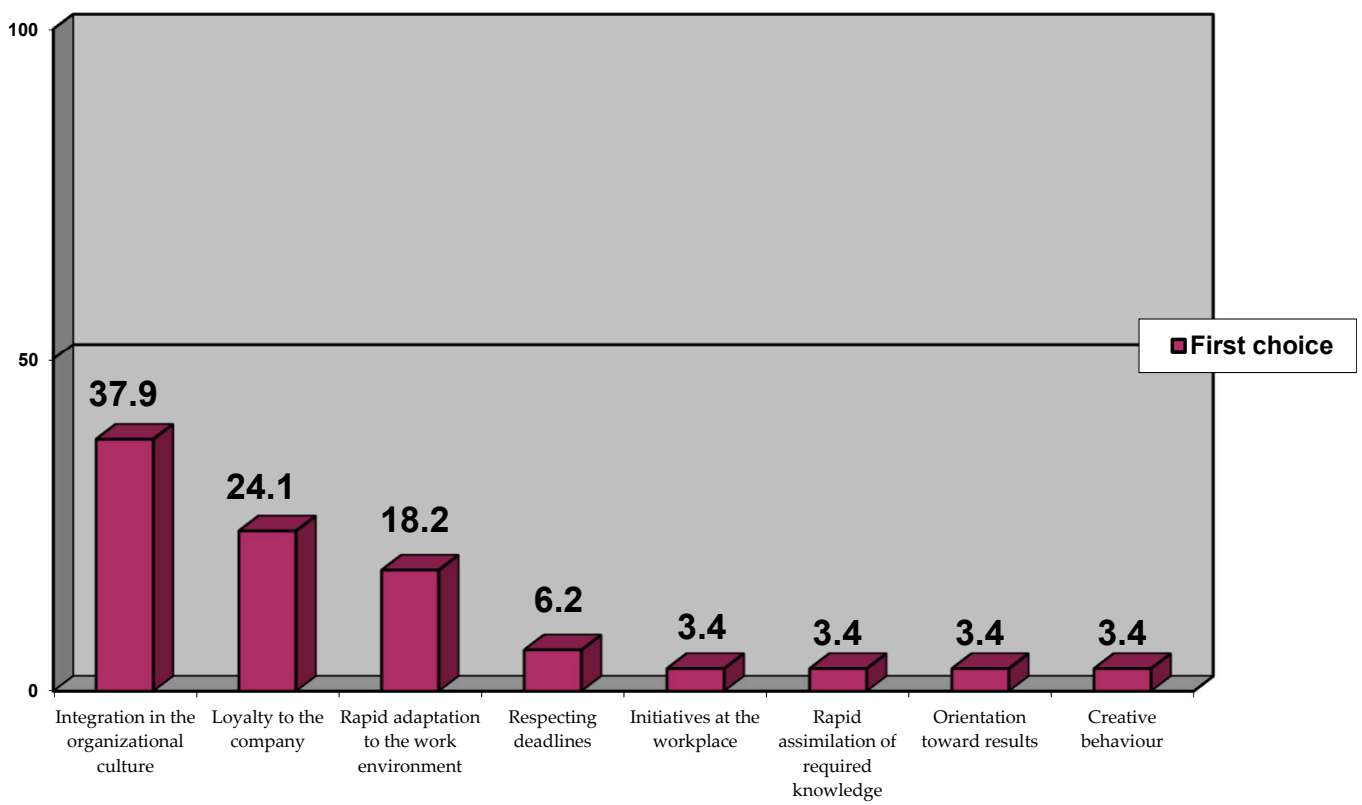

Figure 11. Expectations of the employers towards the employees (\%)

The employers appreciate in the potential employees the capacity of being themselves, of being open, adaptable and loyal. During the interview, they may use questions that would bring to light character, aptitudes, as well as rapid adapting to job requirement, and also meeting deadlines. Especially important are integration capacity in the organization's culture, creativity, initiative at the workplace. 
For the young at the beginning of their carrier, access to as much information as possible regarding the employing company, the expectations regarding the ideal candidate is important.

A candidate will convince by his /her personality, experience, the way he/she looks at his/her professional advancement, aptitudes showing that he/she might bring a plus value to the company. A common factor regarding the expectations of the employers is volunteering, involvement in various activities during the education years, stages of practice. Participation in these activities is looked upon by the employers as a way of gaining experience.

The same work experience is seen both by the graduates and the employers as key-element in carrier promotion and advancement, followed by the level of qualification attained, but also the existence of a personal and professional development plan, first of all by participating in training courses (Fig. 12). This compatibility of ideas between the two lots of subjects supports the hypothesis of the study.

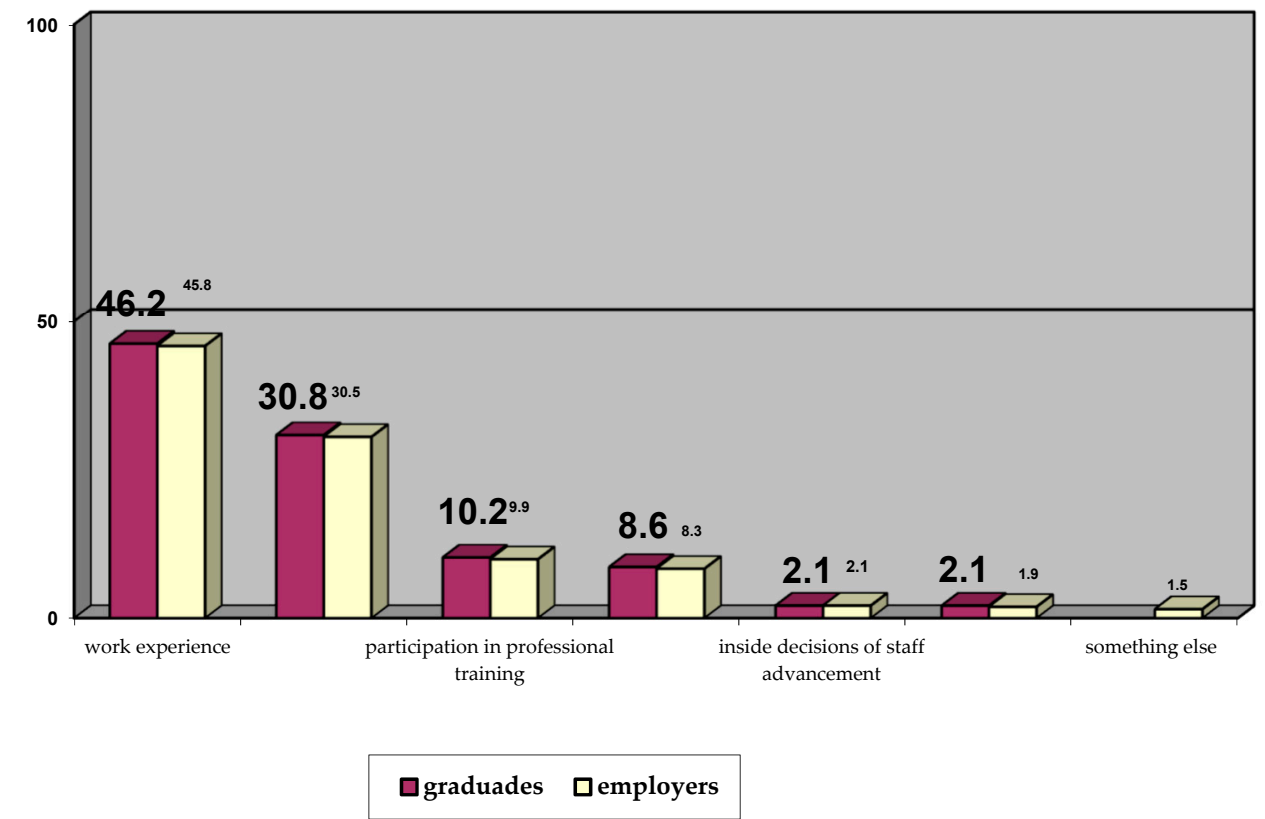

Figure 12. Carrier advancement possibilities, in the opinion of graduates and employers (\%)

4.2.4. Present limits of labour market 


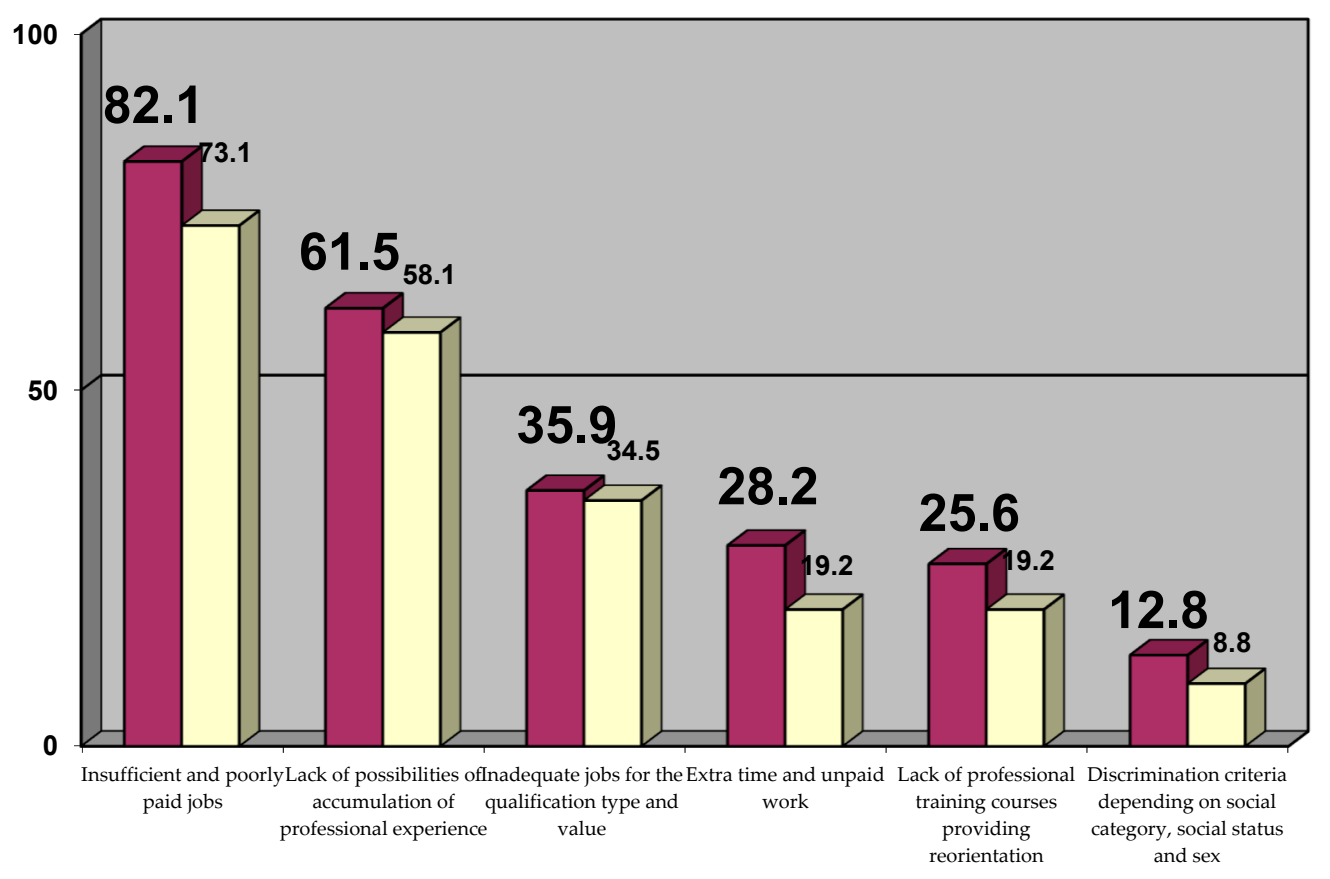

口graduades $\square$ employers

Figure 13. Labour market limits in the opinion of graduates and employers (\%)

The comparison between the two lots of respondents points out a relative similarity of opinions regarding the limits existing in Romania's labour market, the idea that supports the hypothesis of our study. Thus, the variant with most of the choices, both of the graduates and of the employers, is represented by the problem of insufficient and poorly paid jobs. One should mention however, that with the graduates, among the aspects mentioned as limits of the labour market, we may also find lack of possibility of accumulating professional experience, a requirement that is absolutely necessary for hiring, but also the existence of jobs that do not match the value and type of qualification, an aspect which should be in the attention of the universities.

\subsubsection{Opportunities existing on the labor market}

The data presented in Figure 14 show the success of the action taken by the companies involved in the pilot study, involving students interested in long-term internships, resulting in graduates with higher education, experienced in the workplace and motivated to remain active actors in the labor market work in the native country. In order to halt the emigration of young people with higher education, not only the labor market must be flexible and adaptable, but also the educational offer of higher education, the collaboration between the two environments being the essential condition for an adequate insertion on the labor market.

Granting the merit and the responsibility of the academic environment for the development of professional competencies is highlighted in both groups of respondents. On the one hand, it is the percentage of one third of those who declare the inconsistency between the graduated specialization and the availability of jobs (figure 13, figure 14), and on the other hand the broad opinion shared by employers, according to which the educational system needs to adapt its curricula and offer the future labor force anchored in the realities of the labor market. 


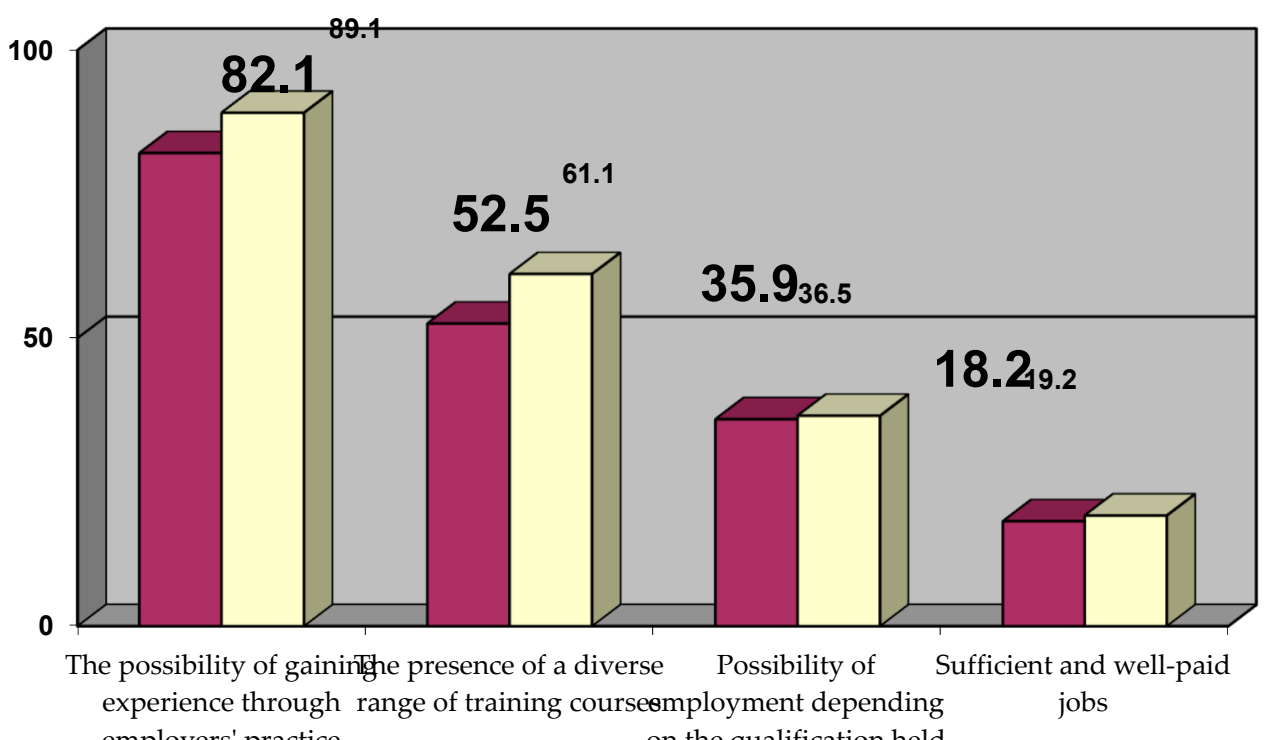
employers' practice on the qualification held programs

\section{口graduades Demployers}

Figure 14. Labour market opportunities in the opinion of graduates and employers (\%)

The pressure exerted at university level is also highlighted by the data presented in the correlation tables 7, 8 and 9, obtained by calculating the Spearman correlation coefficient, according to which statistically significant positive correlations are signaled.

Table 7. Correlation between the importance given by employers to analytical thinking and the need for higher education to improve other competencies

\begin{tabular}{|c|c|c|c|c|c|c|}
\hline & & & $\begin{array}{c}\text { The need for } \\
\text { higher education to } \\
\text { improve analytical } \\
\text { thinking }\end{array}$ & $\begin{array}{l}\text { The need for } \\
\text { higher education } \\
\text { to improve the } \\
\text { ability to learn } \\
\text { quickly }\end{array}$ & $\begin{array}{l}\text { The need for higher } \\
\text { education to } \\
\text { improve the ability } \\
\text { to mobilize the } \\
\text { capacities of others }\end{array}$ & $\begin{array}{l}\text { The need for } \\
\text { higher } \\
\text { education to } \\
\text { find new ideas } \\
\text { and solutions }\end{array}$ \\
\hline \multirow[t]{3}{*}{ Spearman's rho } & \multirow{3}{*}{$\begin{array}{c}\text { The importance } \\
\text { given by } \\
\text { employers to } \\
\text { analytical } \\
\text { thinking }\end{array}$} & $\begin{array}{l}\text { Correlation } \\
\text { Coefficient }\end{array}$ &, $616^{* *}$ &, $597^{* *}$ &, $717^{* *}$ &, $597^{* *}$ \\
\hline & & Sig. (2-tailed) & ,002 & ,002 & ,000 & ,002 \\
\hline & & $\mathrm{N}$ & 20 & 21 & 20 & 21 \\
\hline
\end{tabular}

**. Correlation is significant at the 0.01 level (2-tailed).

Table 8. Correlation between the importance given by employers to the ability to work under stress and the need for higher education to improve other competencies

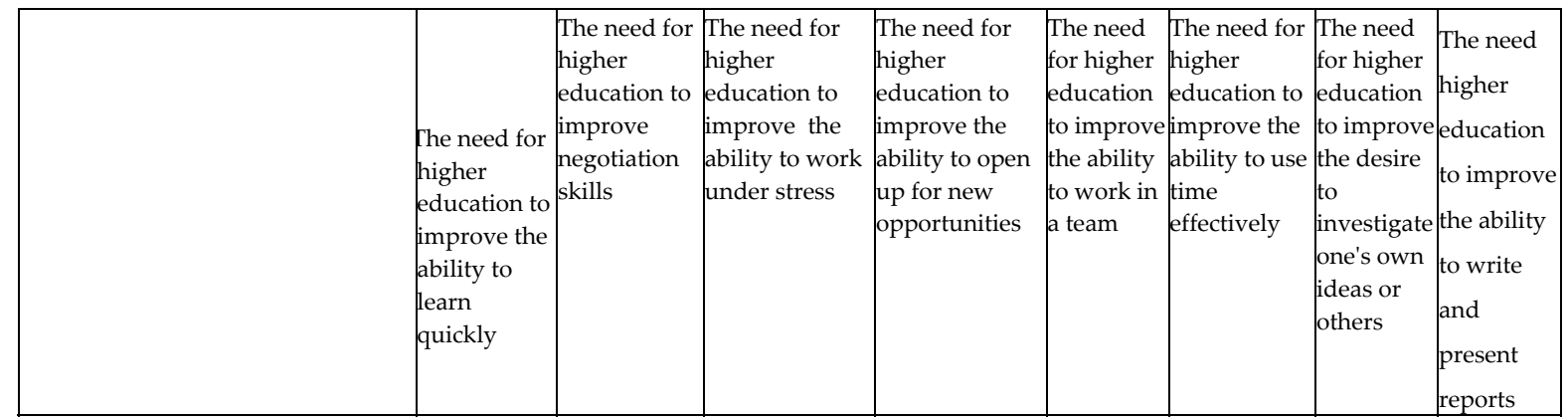




\begin{tabular}{|c|c|c|c|c|c|c|c|c|c|c|}
\hline \multicolumn{3}{|c|}{\begin{tabular}{|l|l|} 
Spearman'sImportance & Correlation
\end{tabular}} & \multirow[b]{2}{*}{$683^{* *}$} & \multirow[b]{2}{*}{,622** } & \multirow[b]{2}{*}{,778 } & \multirow[b]{2}{*}{$622^{* *}$} & \multirow[b]{2}{*}{$692^{* *}$} & \multirow[b]{2}{*}{, $576^{* *}$} & \multirow[b]{2}{*}{,782** } & \multirow[b]{2}{*}{$644^{*}$} \\
\hline rho & $\begin{array}{ll}\text { given } & \text { by } \\
\text { employers } & \text { to } \\
\text { the ability } & \text { to }\end{array}$ & Coefficient & & & & & & & & \\
\hline & \multirow[t]{2}{*}{$\begin{array}{l}\text { the ability to } \\
\text { work under } \\
\text { stress }\end{array}$} & $\begin{array}{ll}\text { Sig. } & (2- \\
\text { tailed) } & \\
\end{array}$ & , 000 & ,002 & , 000 & ,001 & ,000 & ,003 & 000 &, 001 \\
\hline & & $\mathrm{N}$ & 23 & 20 & 23 & 21 & 22 & 21 & 20 & 20 \\
\hline
\end{tabular}

**. Correlation is significant at the 0.01 level (2-tailed).

Table 9. Correlation between the importance given by the employer to the desire to investigate their own ideas or others and the need for higher education to improve other competencies

\begin{tabular}{|c|c|c|c|c|c|c|}
\hline & & & $\begin{array}{l}\text { The need for } \\
\text { higher education } \\
\text { to improve } \\
\text { analytical } \\
\text { thinking }\end{array}$ & $\begin{array}{l}\text { The need for } \\
\text { higher } \\
\text { education to } \\
\text { improve the } \\
\text { ability to learnf } \\
\text { quickly }\end{array}$ & $\begin{array}{l}\text { The need for } \\
\text { higher education } \\
\text { to improve the } \\
\text { ability to open up } \\
\text { for new } \\
\text { opportunities }\end{array}$ & $\begin{array}{l}\text { The need for higher } \\
\text { education to } \\
\text { improve the desire } \\
\text { to investigate one's } \\
\text { own ideas or others }\end{array}$ \\
\hline \multirow[t]{4}{*}{$\begin{array}{l}\text { Spearman's } \\
\text { rho }\end{array}$} & \multirow{3}{*}{$\begin{array}{l}\text { The } \\
\text { importance } \\
\text { given by the } \\
\text { employer to } \\
\text { the desire to } \\
\text { investigate }\end{array}$} & $\begin{array}{l}\text { Correlation } \\
\text { Coefficient }\end{array}$ & ,626** & ,768** & ,663 & ,712** \\
\hline & & \begin{tabular}{|ll} 
Sig. \\
tailed $)$
\end{tabular} & 002 & 000, & 001, & 000, \\
\hline & & $\mathrm{N}$ & & & & \\
\hline & $\begin{array}{l}\text { their } \\
\text { ideas } \\
\text { others }\end{array}$ & & 19 & 20 & 19 & 20 \\
\hline
\end{tabular}

**. Correlation is significant at the 0.01 level (2-tailed).

\section{Discussion and Conclusions}

The hypothesis on which our entire research was based, namely "We estimate that there are no significant differences between the labor market needs and the outcome of the educational system", has been partially confirmed.

For the young at the beginning of their carrier, it is important to have access to as much information as possible regarding the employing companies, and the expectations of those on the ideal candidate, this being the main reason of maintaining an active partnership between the two media - academic and economic, its final goal being an increase of the level of employability of the university graduates.

Nowadays, more and more young people have been employed since the student years. This is due to financial problems or the desire for self-improvement. Internships or practice programs offered by business environment are a very effective way to gain experience and improve personal curriculum vitae. Most young people, once they leave school, start building a career. Each of them seeks at least one source of motivation and a professional destination.

The importance and attractiveness of such an internship is to acquire and develop applied professional skills such as teamwork or project management, the chance to gain real professional experience and ultimately to get a permanent job in the workplace chosen. There are quite a lot of employers, plenty of renowned companies that lend a hand to young people, giving them the chance to start somewhere, learn directly from specialists.

The experience gained during such an internship is very important, especially because nowadays the experience matters more than the many diplomas or courses you have attended. Most employers are looking for experienced or at least willing people to learn and accumulate as much information as possible in the shortest possible time. Young participants at a practice stage will have countless advantages: interaction with professionals in the field, the opportunity to participate in training and theoretical and practical training sessions, work within competitive teams, and result orientation. 
On the other hand, through these internship programs, employers have the opportunity to attract valuable young people to their company, whom they can form, guide and then hire on a permanent basis. Selecting a student or a fresh graduate in a practice program involves earnestness, orientation towards learning and refinement, as well as openness to acquire new professional skills.

It is possible to discover with the help of the media the companies that organize such practice programs. A practice internship at a renowned company can be a big step forward towards a successful career. It is true that these programs can also be used to promote the image of the company that organizes them but at the same time it is a great opportunity for students or graduates to figure out which profession they want to pursue in the future and take the first steps in that direction.

In order for young graduates to build a successful career in their native country that educated them as future specialists, it becomes imperative that the academic environment innovate through measures that include: restructuring the university curriculum, promoting student-centered learning, introduction and improvement of the permanent training system "Long life learning" and broadening the specific education offer responds to the needs of the market, maintaining active partnerships with the business environment, introduction through collaboration with specialized institutions a line of high professionalism in education and in policy making on education, adapting study programs to new labor market standards and to the development needs of the knowledge society, the mandatory introduction of enrichment programs in all forms of education. These programs will ensure permanent modernization and adaptation to the new education system

For an activity to be effective, it must be anticipated / planned / addressed from a global perspective, taking into account the four types of development capital: human, economic, social and environmental.

Gary S. Becker, the uncontested leader of the human capital school, developed the theory of investment in human capital, and the concept of human capital return on investment [46]. Thus Becker built a complex theory of the role of education in economic growth. He classified human capital in the same way as physical means of production: additional investments in human capital, through education, training and medical treatment, and maintaining increased productivity as the ultimate goal.

As for the main point of the research, that of focusing efforts on education and training as means of developing knowledge and skills, and on employment and productivity, respectively, as an effect of investment on educational capital, in 2001, the Organization for Economic Cooperation and Development gave the closest definition for the term human capital, referring to the sum of knowledge, skills, competencies and attributes incorporated in individuals, that facilitate the creation of personal, social and economic welfare.

In this way, higher education institutions that address holistic activities can be characterized as having a responsible way of action, ensuring a high level of long-term competitiveness.

It is therefore advisable for university management to understand and take into account the strategic context, impact area, and the importance of social responsibility. Then it is necessary to clarify the university objectives and implement the principle of social responsibility, taking into account the specific problems faced by the institution as well as its opportunities.

Summing up, we could say that although there have been many attempts to reform the education system, through the formulation and development of various programs and methodologies, in order to ensure sustainable development, many of these did not have the expected effect, yet it is an important step, a starting point for developing an innovative way of organizing the educational structure.

In our opinion, when it comes to reforming education, we must mainly focus on the evolution of education time of each level, from preschool to postgraduate and analyzed strengths and weaknesses. Like suggestions reforming the educational system, we go on the idea of highlighting strengths and balance between practical teaching and theoretical methods, focusing on the practical side, the introduction of counseling programs to help each preschool, student or student in a direction appropriate to him, be helped to make the right decisions through clear arguments, taking into account their desires, passions and talents. Also, another point to be correlated with the above, we 
could talk about the efficiency and the way of teaching, which, in our opinion, should be dynamic, based on innovation and interactive methods.

Universities have the necessary capacity to develop the intellectual framework in support of practical applications on the concept of sustainable development. Higher education institutions, as academic leaders, have the capacity to agree on academic disciplines on large and complex issues, to mobilize resources, to create incentives and programs for skills development, and most importantly to lead by example in to promote and implement sustainable development education.

Author Contributions: Both authors conceived the idea of research. Eduard Edelhauser has been working on creating the formal framework for implementing questionnaires. Eduard Edelhauser was the author who worked on statistical data processing. Roxana Plesa designed the research tools. Roxana Plesa was the author responsible for the literature review and for interpreting the results. Both wrote the manuscris and approved the final manuscript.

Conflicts of Interest: The authors declare no conflict of interest. 


\section{References}

1. Bessant, S.E.; Robinson, Z.P.; Ormerod, R.M. Neoliberalism, new public management and the sustainable development agenda of higher education: History, contradictions and synergies. Environ. Educ. Res. 2015, 21, pp.417-432.

2. Wright, T.S. Definitions and frameworks for environmental sustainability in higher education. High. Educ. Policy 2002, 15, pp.105-120.

3. Van Weenen, H. Towards a vision of a sustainable university. Int. J. Sustain. High. Educ. 2000, 1, pp.20-34.

4. Corcoran, P.B.;Wals, A.E. Higher Education and the Challenge of Sustainability: Problematics, Promise and Practice; Kluwer Academic Press: Dordrecht, The Netherlands, 2004; pp. 7-19.

5. Gough, S.; Scott, W. Higher Education and Sustainable Development: Paradox and Possibility; Routledge: London, UK, 2008.

6. European Commission. Eurostat. Available online: http://ec.europa.eu/eurostat/statisticsexplained/index.php?title=Special\%3ASearch\&profile=default\&searc

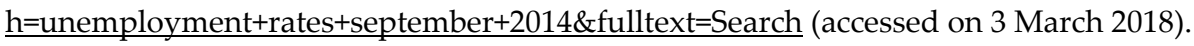

7. Szilagyi, A. Manualul consultantului în carieră, Institutul European: Iași, 2008, ISBN 978-973-611-514-1, (In Romanian).

8. European Commission, Eurobarometer, Employers' perception of graduate employability, Available online: http://ec.europa.eu/public opinion/flash/fl 304 en.pdf (accessed on 7 March 2018).

9. EUROSTAT, Combating poverty and social exclusion. A statistical portrait of the European Union, Available online: http://ec.europa.eu/eurostat/documents/3217494/5723553/KS-EP-09-001EN.PDF (accessed on 7 March 2018).

10. UECNCFPA, DOCIS- Development of an operational system of qualifications in higher education in Romania, Available online: http://www.anc.edu.ro/?page id=183 (accessed on 2 March 2018).

11. www.insse.ro (accessed on 1 March 2018).

12. World Commission on Environment and Development, Oxford University Press, Available online: http://www.un-documents.net/our-common-future.pdf (accessed on 9 March 2018).

13. Baek, W., Cho, J. Challenging the Sustainability of an Education System of Evaluation and Labor Market Outcomes, Sustainability 2015, 7, pp.16060-16075.

14. http://www.unesco.org/new/en/education/themes/leading-the-international-agenda/ (accessed on 9 March 2018).

15. Sammalisto, K.; Sundström, A.; Von Haartman, R.; Holm, T.; Yao, Z. Learning about sustainability-what influences students' self-perceived sustainability actions after undergraduate education? Sustainability, 2016, 8, 510.

16. http://www.actionamresponsabil.ro/avem-nevoie-de-educatie-în-spiritul-dezvoltării-durabile/14595 (accessed on 9 March 2018).

17. Stanef, M.R. Sistemul educaţional din România, disparităţi dintre mediul urban şi cel rural, Economie teoretică şi aplicată, Volumul XX, 2013, 1, pp. 83-93.

18. Mourshed, M.; Chijioke, C.; Barber, M. How the worlds most improved school systems keep getting better, McKinsey\&Company, Available online: http://mckinseyonsociety.com/downloads/reports/ (accessed on 9 March 2018).

19. European Commission. Europe 2020 strategy, available online: http://ec.europa.eu/europe2020/pdf/europe2020stocktaking en.pdf (accessed on 6 March 2018).

20. http://www.unece.org/env/esd (accessed on 10 March 2018).

21. Kremer, M.; Schrijvers, E.; Holtslag, J.W. How to make migration work. In Making Migration Work: The Future of Labour Migration in the European Union; Holtslag, J.W., Kremer, M., Schrijvers, E., Eds.; Amsterdam University Press: Amsterdam, The Netherlands, 2013; pp. 13-38.

22. http://strategia.cndd.ro/docs/comentarii/10 fc.pdf (accessed on 9 March 2018).

23. Papademetriou, D.G. The global and European neighbourhood migration systems: Trends, policy choices, governance challenges and a look ahead. In Making Migration Work: The Future of Labour Migration in the European Union; Holtslag, J.W., Kremer, M., Schrijvers, E., eds., Amsterdam University Press, Amsterdam, The Netherlands, 2013; pp. 39-50.

24. Ștefănescu-Mihăilă, R.O. Social Investment, Economic Growth and Labor Market Performance: Case Study-Romania. Sustainability 2015, 7, 2961-2979. 
25. Gander, J.P. A dynamic managerial theory of corruption and productivity among firms in developing countries. Econ. Manag. Financ. Mark. 2014, 9, pp.54-65.

26. Nica, E. Corporate practices in higher education. Psychosoc. Issues Hum. Resour. Manag. 2014, 2, pp.51-56.

27. Capdevila, I.; Bruno, J.; Jofre, L. Curriculum greening and environmental research co-ordination at the Technical University of Catalonia, Barcelona. J. Clean. Prod. 2002, 10, pp.25-31.

28. Desha, C.J.; Hargroves, K.; Smith, M.H. Addressing the time lag dilemma in curriculum renewal towards engineering education for sustainable development. Int. J. Sustain. High. Educ. 2009, 10, pp.184-199.

29. Stubbs, W.; Schapper, J. Two approaches to curriculum development for educating for sustainability and CSR. Int. J. Sustain. High. Educ. 2011, 12, pp.259-268.

30. Lozano, R., Merrill, M.Y., Sammalisto, K., Ceulemans, K., Lozano, F.J. Connecting Competences and Pedagogical Approaches for Sustainable Development in Higher Education: A Literature Review and Framework Proposal, Sustainability 2017, 9, 1889.

31. MacVaugh, J.; Norton, M. Introducing sustainability into business education contexts using active learning. Int. J. Sustain. High. Educ. 2012, 13, pp.72-87.

32. Baek, W., Cho, J. Identifying the Virtuous Circle of Humanity Education and Post-Graduate Employment: Evidence from a Confucian Country, Sustainability 2018, 10, 202.

33. Cortese, A.D. The critical role of higher education in creating a sustainable future. Plan. High. Educ. 2003, 31, pp. 15-22.

34. Lozano, R.; Lukman, R.; Lozano, F.J.F.J.; Huisingh, D.; Lambrechts, W. Declarations for sustainability in higher education: becoming better leaders, through addressing the university system. J. Clean. Prod. 2013, 48 , pp. 10-19.

35. Velazquez, L.; Munguia, N.; Platt, A.; Taddei, J. Sustainable University: What can be the matter? J. Clean. Prod. 2006, 14, pp.810-819.

36. Goschin, Z. et.al. Emigrația românească: implicații economice și demografice, ASE: București, 2012, ISBN 978606-505-534-6 (In Romanian).

37. Goschin Z. et.al. Romanian Migration and Remittances in an Economic Crisis Context, ASE: București, 2014, ISBN 978-606-505-820-0.

38. Kahanec, M. Labor mobility in an enlarged European Union. In International Handbook on the Economics of Migration; Constant, A.F., Klaus, F., Zimmermann, K.F., eds.; Edward Elgar, Cheltenham-Northampton, MA, USA, 2013; pp. 137-152.

39. Engbersen, G. Labour migration from Central and Eastern Europe and the implications for integration policy. In Making Migration Work: The Future of Labour Migration in the European Union; Holtslag, J.W., Kremer, M., Schrijvers, E., Eds.; Amsterdam University Press, Amsterdam, The Netherlands, 2013; pp. 105122.

40. Goschin, Z.; Constantin, D.L. Adaptability and change - national and regional dimensions in the Romanian economy. In Adaptability and change: The regional dimensions in Central and Eastern Europe, Gorzelak, G.; Goh, C.; Fazekas, K. (eds), Wydawnictwo Naukowe Scholar Publishing House, Warsaw, 2012, pp. 299-315, ISBN 978-83-7383-549-8.

41. Nica, E. Labor Market Determinants of Migration Flows in Europe. Sustainability, 2015, 7, pp. $634-647$.

42. Anghel, R.G.; Horvath I. Sociologia migrației. Teorii și studii de caz românești, Polirom: Iași, 2009, 978-973-461304-5 (In Romanian).

43. Ambrosini, W.; Mayer, K.; Peri, G.; Radu, D. The Selection of Migrants and Returnees: Evidence from Romania and Implications, National Bureau of Economic Research WP 16912, 2011, Available online: http://www.anc.edu.ro/?page id=183 (accessed on 11 March 2018).

44. Roman, M.; Voicu, C. Several socio-economic effects of migration labor force on emigration countries. Case of Romania. Theoretical and Applied Economics, 2010, XVII, 7(548), pp. 50-65.

45. Jigău, M. Consilierea carierei, Editura Sigma: București, 2007, ISBN 978-973-649-340-9, (In Romanian).

46. Lazăr, L. Evaluarea Capitalului Uman-Strategii de Ocupare a Forței de Muncă; Risoprint: Cluj-Napoca, 2005, ISBN 973-. 656-8112-1 (In Romanian). 